\title{
A Different Point of View of Glutathione Peroxidase: its Relationship to the Metabolic Changes Associated with Nutritional Management in Assaf ovine breed
}

\begin{abstract}
Summary
We considered the role played by selenium-dependent glutathione peroxidase (GSH-PX) in relation to the metabolic changes due to nutritional management in a flock of the Assaf breed in Spain, housed in an intensive management system. Our objective was to examine the relationship between the nutritional management of this flock during different productive stages and GSH-Px. The modifications of ASAT and CK activities, closely connected to the pathological changes in GSH-Px values, were also recorded. The animals were divided into two groups: control and experimental ewes.

Our results showed that neither physiological condition nor litter size had any influence on the GSH-Px values; the main modifications were due to the diet of these animals, especially if the diet was rich in essential farty acids. The evolution of ASAT and CK activities, and their relationship to GSH-Px and nutrition, is also described.
\end{abstract}

Key Words: glutathione peroxidase, metabolism, ewe ${ }_{i}$ pregnancy

\section{Zusammenfassung}

Titel der Arbeit: Ein anderer Aspekt der Glutathionperoxidase: Thre Beziehung zu metabolischen Veränderungen im Zusammenhang mit dem Futterungsmanagement bei Assaf-Schafen Untersucht wurde die Bedeutung der Selen-abhängigen Glutathion-Peroxidase(GSH-Px) in Bezug auf futterungsbedingte Stoffwechselverănderungen in einer Herde von Assaf-Schafen unter intensiven Haltungsbedingungen. Fragestellung war ein möglicher Zusammenhang zwischen dem Futterungsmanagement in verschiedenen Produktionsphasen und der GSH-Px-Aktivität. Desweiteren wurden Änderungen der AST- und CKAktivitat berlicksichtigt, welche mit der GSH-Px eng verknupf sind. Die untersuchten Mutterschafe wurden in Kontroll- und Versuchsgruppe unterteilt. Die Ergebnisse zeigen, daß die GSH-Px-Werte weder durch den physiologischen Zustand noch durch die Zahl der Lämmer beeinflusst wurden. Die stärksten Veränderungen ergaben sich durch die Futterung, vor allem durch Rationen mit hohem Gehalt an essentiellen Fettsäuren. Die Entwicklung der AST und CK-AKtivitat sowie deren Beziehung zur GSH-Px werden ebenfalis beschrieben.

Schlusselwöter: Glutathione-Peroxidase, Stoffwechsel, Mutterschafe, Trächtigkeit

\section{Introduction}

Many reactions required for the maintenance of normal metabolism and the production of energy in the cell produce potentially toxic free radicals as unwanted by-products (CHESTER and ARTHUR, 1988). Normally, the body is protected against reactive oxygen metabolites and their toxic products by a wide range of known defence mechanisms, like antioxidant enzymes. Several essential nutrients are involved in the manufacture of known components of antioxidant defence. In this sense, MILLER et al. (1993) explained the role played by nutritional management in this respect, 
Selenium-dependent GSH-Px plays an important role in the cellular antioxidant defence system. This enzyme reduces hydrogen peroxide and lipid hydroperoxides, potentially harmful prooxidants that may promote peroxidation of polyunsatured phospholipids in biological membranes (LÓPEZ ALONSO et al., 1997).

It is well known that normal metabolism may be modified under many conditions, such as physiological status. During pregnancy or lactation large amounts of free radicals occur as intermediate products in the metabolic pathways (CASTILLO et at., 1998). When, during these situations, the animals receive an unbalanced diet the antioxidative systems can be overloaded. If free radicals are not eliminated, these metabolic pathways will easily be deregulated, bringing about pathological conditions; the final consequence of which will be the inability to maintain reproduction (LOPEZ ALONSO et al, 1998).

Many studies (MILLER et al., 1993) point out that the antioxidant requirements of dairy animals may be higher than is generally recognized, and intakes of the antioxidants needed to control reactive oxygen metabolite balance effectively may exceed the amounts supplied by average feeds. In this sense, supplementation with all knowri nutrients required for antioxidant defence in adequate and balanced amounts would be beneficial, although additional research is needed, however, to identify optimal amounts of each nutrient.

For this reason, we are studying the metabolic profile of the Assaf breed in Spain. The latter represents a small percentage of the total dairy ovine census in Castilla-León region and we have found that there are no studies conducted solely on this breed for understanding their physiology, nutritional requirements, diseases, management and appropriate breeding methods. In a prior report, based on the Assaf breed (CASTILLO et al., 1999), we pointed out that there is a widespread misunderstanding in relation to the nutritional management of this breed. In fact, in the Castilla-León region many ovine flocks present a similar nutritional programme, independently of the ovine breed and their productions. We concluded in that report the presence of two critical moments in relation to diet, and their metabolic consequences: early and late pregnancy. At these moments the ewes received a diet based on low-energy foods and excessive concentrate intake, respectively.

Our objective now is to examine a possible relationship between this nutritional management and the evolution of one of the most important antioxidant enzymes in the body: GSH-Px. The modifications of ASAT and CK activities closely connected to the pathological changes in GSH-Px values were also recorded.

\section{Material and Methods}

\section{Animals}

The study was conducted on a flock located in Valladolid, in central Spain. Thirty-five ewes of the Assaf breed, ranging from 3 to 6 years of age and of an average weight of $60 \mathrm{Kg}$, were selected. The animals were housed in an intensive management system.

The animals were randomly assigned to 2 groups: the experimental group $(n=25)$ comprised those that were going to become pregnant and lactate during the experiment, and the control group comprised 10 non-pregnant animals. The experimental ewes were synchronized in anoestrus, using a standard technique 
(BRITT, 1989). Three weeks before mating all the ewes were injected with $50 \mathrm{mg}$ of barium selenate, subcutaneously (Zooselen®, Esteve Laboratories, Spain) in accordance with to prior studies on sheep (ZACHARA et al., 1993; SAEZ et al., 1996). All the animals were housed in the same environmental conditions and received the same diet (Fig.). Pregnancy was diagnosed in the second month after synchronization by ultrasound scanning, establishing at this moment two groups: single $(n=11)$ and twin pregnancies $(n=14)$.

1. Diet for the dry period (from anoestrus $\rightarrow 3^{\text {rd }}$. month of pregnancy)

- Alfalfa hay

- Trace element and vitamin supplement (Baymix, Ovilac® Bayer)*

2. Diet for late pregnancy (from $3^{\text {rd }}$. month $\rightarrow$ parturition)

- Mixed forage (alfalfa and ryegrass)

- Concentrate (corn silage, soybean meal, sunflower meal)

- Trace element and vitamin supplement (Baymix, Ovilac® Bayer)"

3. After delivery until 10 days after parturition the concentrate of this diet was supressed and the animals were maintained solely on forage.

4. Lactation diet (from 10 days after parturition and during lactation)

* Corn silage

- Soybean meal

- Alfalfa hay

- Trace element and vitamin supplement (Baymix, Ovilac@ Bayer)*

Fig.: Nutritional protocol of the flock (Ernahrungsprotokoll der Herde)

(") Composition of the Baymix, Ovilac $\otimes$ (Composition for $100 \mathrm{Kg}$ ): Vitamin A: $40,000.000$ UI: Vitamin D3; 8.000.000 Ul; Vitamin E: 100

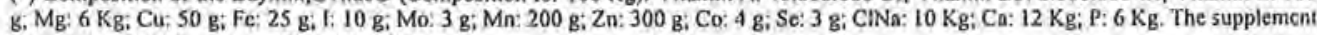
was administered in a dose of $20 \mathrm{~g} / \mathrm{Kg} \mathrm{DM}$.

\section{Sample collection and analyses}

Blood samples were taken from selected ewes between 8.00 and 9.30 prior to the morning feeding. Sampling began in the anoestrus period, when synchronization was incuced, considering it as a baseline sample. The following samples were taken on the 75th day and the 90th day of pregnancy, 10 days before and after parturition and finally, one month after parturition (lactation). This protocol was carried out from March to October.

Blood samples were collected by jugular venipuncture. Each sample was placed into heparinized tubes and tubes for serum separation. GSH-Px was measured with a commercial kit (Ransel, (B) Randox Laboratories, U.K.) based on the method of PAGLIA \& VALENTINE (1967). Haemoglobin was determined by the standard cyanmethaemoglobin method (HAINLINE, 1958). Serum creatin kinase (CK) and aspartate aminotransferase (ASAT) activities were expressed in International Units per liter (IU/l) and were assayed using kinetic procedures with commercial reagents (Cromatest $($ Reagents, Knickerbocker Laboratories, Spain). 
Statistical analyses

The reported values are mean \pm std error. A statistical test was performed using a twoway analysis of variance to check the influence of physiological status and litter size on the blood parameters. The statistical differences were established taking into account a $\mathrm{p}<0.05$ (WILLIAMS, 1994).

\section{Results}

Developmental changes in the studied parameters in both experimental and control ewes, and the significance levels appreciated between pregnant and barren animals during the experience are reflected in Table 1. Table 2 shows the mean values in ewes carrying singles and twins.

Table 1

Mean values ( $\mu \pm s t$, error) of the different parameters in control and pregnant ewes during the different phases of the study (Durchschnittswerte ( $\mu \pm$ Standard Abweichung) der verschiedenen Parameter Kontrollschafe und bei trächtigen Schafen wăhrend der verschiedenen Versuchsphasen)

\begin{tabular}{|c|c|c|c|}
\hline \multirow[t]{2}{*}{ Phase } & \multirow{2}{*}{$\begin{array}{cc}\text { GSH-Px } & (\mathrm{TU} / \mathrm{g} \mathrm{Hb}) \\
\text { Control } & \text { Pregnant }\end{array}$} & $\operatorname{ASAT}(\mathrm{IU} / \mathrm{L})$ & CK (IU/L) \\
\hline & & Pregnani & Control Pregnant \\
\hline Baseline & $605.23 \pm 17.61^{1 / a}$ & $69.0 \pm 3.63^{1 / a}$ & $15.44 \pm 2.67^{1 / 2}$ \\
\hline 75 day & $754.21 \pm 19,21^{\mathrm{II}} \quad 817.43 \pm 28.54^{\mathrm{b}}$ & $62.90 \pm 4.59^{11} \quad 62.35 \pm 4.34^{6}$ & $18.70 \pm 3.35^{1} \quad 14.04 \pm 1.39^{t}$ \\
\hline Comparison & N.S. & N.S. & N.S. \\
\hline 90 day & $803.70 \pm 60.17^{111} \quad 872.27 \pm 28.70^{12}$ & $69.18 \pm 6.99^{1} \quad 64.50 \pm 4.97^{2}$ & $24.50 \pm 3.71^{1} \quad 16.99 \pm 1.62^{2}$ \\
\hline Comparison & N.S. & N.S. & 0.045 \\
\hline 10 days b.p. & $469.54 \pm 20.25^{1 V} \quad 461.50 \pm 14.68^{\circ}$ & $37.75 \pm 1.83^{\mathrm{III}}$ & $16.50 \pm 2.29^{t} \quad 20.13 \pm 3.41^{2}$ \\
\hline Comparisor: & $\begin{array}{l}\text { N.S. } \\
\end{array}$ & N.S. & N.S. \\
\hline 10 days a.p. & $465.15 \pm 55.87^{\text {IV }} \quad 470.72 \pm 15.36^{c}$ & $41.66 \pm 2.72^{1 V}$ & $27.05 \pm 8.34^{1}$ \\
\hline Comparison & N.S. & 0.010 & N.S. \\
\hline Lactation & $366.35 \pm 39.75^{\mathrm{V}} \quad 340.10 \pm 32.50^{\mathrm{d}}$ & $56.50 \pm 5.54^{11} \quad 63.21 \pm 3.62^{2}$ & $12.72 \pm 2.59^{1} \quad 20.63 \pm 3.94^{2}$ \\
\hline Comparison & N.S. & N.S. & 0.025 \\
\hline
\end{tabular}

b.p. and a.p. mean before and after parturition, respectively.

The letters a, b, c... or signs I, II, III,.. in each column indicate values that are significantly diffetent $(\mathrm{p}<0.05)$, In cach column appears the significance levels appreciated in the comparison between groups during the study.

Tabie 2

Mean values ( $\mu \pm s t d$. error) of the studied parameters in twins and single bearing ewes. There are represented the significance level when we analyzed the effect of litter size (Durchschnittswerte ( $\mu \pm$ Standard Abweichung) der untersuchten Parameter bei Schafen mit Einlings- und bei solchen mit Zwillingstraechtigkeit. Dargestellt ist das Signifikanzniveau bezuglich des Einflusses der Lammerzahl)

\begin{tabular}{clccccc}
\hline Parameier & Group & 75 d pregnancy & 90 d pregnancy & 10 days b.p. & 10 days a.p. & Lactation \\
\hline GSH-Px (UI/g & Singīe & $768.95 \pm 59.96$ & $879.95 \pm 63,23$ & $437.55 \pm 24.20$ & $467.88 \pm 27.21$ & $309.35 \pm 36.55$ \\
Hb) & Twin & $850.55 \pm 32.92$ & $867.94 \pm 31.72$ & $481.45 \pm 15.00$ & $474.04 \pm 13.62$ & $370.86 \pm 54.18$ \\
& & N.S. & N.S. & N.S. & N.S. & N.S. \\
\hline ASAT (IU/L) & Single & $65.80 \pm 5.25$ & $74.50 \pm 9.85$ & $36.00 \pm 2.51$ & $56.71 \pm 4.36$ & $63.00 \pm 3.37$ \\
& Twin & $54.87 \pm 3.14$ & $57.00 \pm 3.08$ & $39.33 \pm 2.09$ & $61.85 \pm 8.42$ & $63.42 \pm 5.65$ \\
& & $\mathbf{0 . 0 4 2}$ & $\mathbf{0 . 0 4 0}$ & N.S. & N.S. & N.S. \\
\hline CK (IU/L) & Single & $14.85 \pm 2.47$ & $17.19 \pm 2.48$ & $20.35 \pm 5.79$ & $18.46 \pm 3.42$ & $26.13 \pm 6.15$ \\
& Twin & $13.23 \pm 1.97$ & $16.84 \pm 2.39$ & $19.94 \pm 4.50$ & $22.00 \pm 3.14$ & $15.12 \pm 4.43$ \\
& & N.S. & N.S. & N.S. & N.S. & $\mathbf{0 . 0 4 0}$ \\
\hline b.p. and g.p. metn before and after parturition, respectively. & & & &
\end{tabular}

Beginning with the GSH-Px evolution, a remarkable fact was that both control and pregnant (single and iwins) groups showed the same evolution without statistical 
differences, reflecting that neither physiological condition nor litter size had any influence on the GSH-Px values. Considering only the behaviour of this enzyme brings out the increase that appears between the anoestrus period and the $90 \mathrm{~d}$ of pregnancy, with a notable decrease in late pregnancy which is maintained after lambing, In lactation the values are the lowest of the study. We wish to point out that in spite of these significative changes, the mean activities of GSH-Px throughout the experiment were within optimal ranges (ZACHARA et al., 1993; SAEZ et al., 1995; MORGANTE et al., 1998).

In reiation to ASAT activity, it is clear that the onset of lactation is the only period that determines statistical differences between the control and experimental groups (lactaking ewes present higher values) whereas the beginning of pregnancy establishes differences between singles and twins (single-bearing ewes show higher activities). In the evaluation of the evolution of ASAT it is interesting to appreciate the notable decrease that appears in all ewes in late pregnancy, parallel to the decrease in GSH-Px
activity.

Lastly, taking into account the results of the CK it is clear that during the experiment, and in spite of the peculiar nutritional management of this flock, the animals did not suffer muscular damage, as is shown by the physiological values during the study (KANEKO, 1989). On the other hand, the CK activities did not change in a significant manner during the experiment although it is possible to observe differences between groups: in the $90 \mathrm{~d}$ of pregnancy and lactation phases if we consider control and experimental groups, and the lactation if we take into account the litter size.

\section{Discussion}

One conclusion that we have reached in this study is that neither physiological condition nor litter size influenced GSH-Px evolution. This can only be explained by taking into account nutritional factors. We think that seasonal trends, under our husbandry conditions, must be carefully considered because the relationship between the animals, the vegetation and the local geology and soil composition is not as close as in grazing animals (ANDRES et al., 1997). WHEATLEY and BECK (1983) pointed out the differences between these two systems in the sense that housed ewes receive a high dry-matter intake which induces the increase in mineral and oligoelement status (including selenium) and hence, in gluthathione activity. In addition, the handling of the different foods (ensilage or haymaking), determines important modifications in their characteristics which do not always run parallel to seasonality. For this reason it is difficult to compare our results with other studies carried out on grazing animals. Thus, we will analyse the changes in GSH-Px activity taking into account the nutritional management of the flock and their metabolic consequences.

Firstly, it is interesting to point out the high levels reached in the early-pregnancy period, which is caused by the effects of barium selenate supplementation. The highest levels reached at $90 \mathrm{~d}$ are because the majority of the glutathione peroxidase in whole blood is incorporated into the red blood cells at the time of erythropoiesis. So the complete response in GSH-Px activity to a Se supplementation will require a time span equal to the average life span of the erythrocyte, which in the case of sheep is 
approximately 120 days (LOPEZ ALONSO et al., 1998). These effects of Se supplementation added to vitamin-mineral supplement are evident if we consider the diet that was fed to the ewes at this moment. Alfalfa-hay is not only a low-energy food, as was demonstrated in a prior report on this same flock (CASTILLO et al., 1999) but gives low levels of Se, essential for glutathione peroxidase synthesis. This is due to their poor Se accumulation (ANDRES et al., 1991) and the high presence of vitamin E antagonists (BEDO et al., 1992; CHURCH, 1993). This fact might be enough to predispose ewes to peroxide intoxication if the animals had not received supplementation.

The notable decrease in late pregnancy can be explained by considering the properties of the specific diet that the animals received. The administration of a rich-concentrate diet gives energy that can be appreciated through a recovery in glucose, triglyceride and NEFA values, the latter higher than those recorded as physiological (CASTILLO et al., 1999). This last coincidence is important for us. The NEFA values in blood have been considered as an indirect measure of feed intake in housed animals (FOX et al., 1991). On the other hand, it is well known that rich-grain diets present high levels of essential fatty acids (McDONALD et al., 1986). An adverse effect of this kind of diet in ruminants is the increased conversion of polyunsatured fatty acids, derived from essential fatty acids, to lipid peroxides. This fact implies an increase in the requirements of antioxidants, like vitamin $E$ and glutathione peroxidase (CLARENBURG, 1992; CAPPA, 1996). In lactation the decrease in GSH-Px advances and can be attributed to the decrease in the protective effect of barium selenate, as described SAEZ et al. (1996).

Finaliy, we wish to study both ASAT and CK enzymes. In relation to the former, the decrease in late pregnancy is significant in relation to the remaining phases. It appears that any phase affects on hepatic activity more than late pregnancy. Nevertheless the ASAT interpretation mighe not only be considered closely connected with physiological condition, but also to the metabolic burden associated with nutritional factors (BRZOSTOWSKY et al., 1995). Low-energy diets, like alfalfa-hay or low levels of concentrate, imply a hepatic effort for triglyceride metabolization as energy supply (BARTLEY, 1989). When the animals receive a diet rich in glucogenic precursors (such as starch) and energy, there is an increase in ruminal propionate production and indirectly, glucogenesis with a lesser hepatic effort (HERDT, 1988). In late pregnancy, and in spite of high NEFA levels, as a result of the feed intake, the recovery in glucose values and the normal ASAT activities indicate the absence of fatty infiltration of the liver in both groups, and especially in pregnant ewes.

The highest ASAT activities in the single-bearing group during early pregnancy might be due to the lesser capacity of these ewes, in comparison to the twin-bearing group, for improving hepatic activity at the beginning of this period (FREETLY and FERRELL, 1997). Finally, the differences that appear between control and pregnant groups after lambing can only be attributed to the increased hepatic activity characteristic of dairy ewes at the onset of lactation (CASTILLO et al., 1999).

The CK values showed the absence of muscular damage, especially when the diet was rich in polyunsatured fatty acid derivates (SMITH et al., 1994). So, little importance might be placed on the changes in serum CK activity, especially when ASAT is 
considered, as WEST (1989) described in the study of normal ovine pregnancy.

\section{References}

ANDRES, S.; NIÑO, A.; JIMENEZ, A.:

Enfermedad del músculo blanco. Ed. Luzán, Spain (1991)

ANDRES, S.; JIMENEZ, A.; MAÑE, M.C.; SANCHEZ, J.; BARRERA, R.:

Relationships between some soil parameters and the blood glutathione peroxidase activity of grazing sheep. The Veterinary Record 141 (1997), 267-268

BARTLEY, J.C.:

Lipid Metabolism and its diseases. In J.J. KANEKO (Editor) Clinical Biochemistry of Domestic Animals. $4^{\text {th }}$. Ed. Academic Press, USA (1989)

BEDO, S.; MEZES, M.; BARCSAK-TOTH, G.:

Blood glutathione peroxidase enzyme activity as an index of selenium release from Permasel in ewes

BRITT, J.H.: Acia Veterinaria Hungarica 40 (1992), 151-154

Inducción y sincronización đe la ovulación. In: E.S.E. HAFEZ (Editor), Reproducción e Inseminación Artificial en Animales Domésticos. $5^{n}$ ed., Interamericana, México (1989), 547-557

BRZOSTOWSKI, H.; MILEWSKI, S.; WASILEWSKA, A.; TANSKI, Z:

The influence of the reproductive cycle on levels of some metabolism indices in ewes. Archivum Veterinarium Polonicum 35 (1995), 54-62

CAPPA, $\mathrm{V}$ :

Importancia y papel del selenio en la alimentación de los bovinos. Veterinaria en Praxis 11 (1996), 15. 21

CASTILLO, C; GARCIA PARTIDA, P,; HERNANDEZ, J.; BENEDITO, J.L.:

Applications of Fencl's equations in the acid-base balance changes related to pregnancy in ewes. Vet. Med.-Czech 43 (1998), 27-31

CASTILLO, C.; HERNANDEZ, J.; LOPEZ, M.; MIRANDA, M.; BENEDITO, J.L.:

Effect of physiological stage and nutritional management on some serum metabolite concentrations in the Assaf ovine breed. Arch. Tierz., Dummerstorf $\$ 2$ (1999), 377-386

CHESTER, J.K.; ARTHUR, J.R.:

Early biochemical defects caused by dietary trace elements deficiencies. Nutrition Research Reviews I (1988), 39-56

CHURCH, C.D.:

El numiante: fisiologla digestiva y nutricion. Ed. Acribia, Spain (1993)

CLARENBURG, R.:

Physiologicai Chemistry of Domestic Animals. Ed. Mosby, USA (1992)

FOX, M.T; GERRELLI, D.; PITT, S.R.; JACOBS, D.E.:

The relationship between appetite and plasma nonesterified fatty acid levels in housed calves. Vet. Res. Comm. 15 (1991), 127-133

FREETLY, H.C.; FERRELL, C.L.:

Oxygen consumption by and blood flow across the portal-drained viscera and liver in pregnant ewes. J. Anim. Sci, 75 (1997), 1950-1955

HAINLINE, A.:

Hemoglobin. In: D.SELIGNON (Editor), Standard Methods of Clinical Chemistry Vol 2, Academic Press, USA (1958), 269-308

HERDT, E.H.:

Fuel homeostasis in ruminants. Vet. Clin. North Am.; Food Anim. Pract. 44 (1988) 2, 213-231

KANEKO, J.J.:

Apendixes. In J.J. KANEKO (Editor), Clinical Biochemistry of Domestic Animals. $4^{\text {th }}$ ed. Academic Press, USA (1989)

LOPEZ ALONSO, M.; MIRANDA, M.; HERNANDEZ, J; CASTILLO, C,; BENEDITO, J.L.:

Glutation peroxidasa (GSH-Px) en las patologias asociadas a deficiencias de selenio en rumiantes. Arch. Med. Vet. XXrX (1997), 171-180

LOPEZ ALONSO, M., CASTILLO, C., MIRANDA, M., HERNANDEZ, J., AYALA, I., BENEDITO, J.L.;

The influence of reproductive stage on the selenium status of sheep in a low-selenium region. Acta Vct. Hung, 46 (1998), 101-109 
McDONALD, P.; EDWARDS, R.A.; GREENHALGH, J.F.D.:

Nutrición Animal. Ed. Acribia, Spain (1986)

MILLER, J.K.; BRZEZINSKA-SLEBODZINSKA, E.; MADSEN, F.C.:

Oxidative stress, antioxidants and animal function. J. Dairy Sci. 76 (1993), 2812-2823

MORGANTE, M.; MCCOY, M.A.; PAUSELLI, M.; BEGHELLI, D.; RANUCCI, S.:

Selenium status in Sardinian dairy ewes. Proc. $6^{\text {th }}$ Congress of Fe.Me,S.P.Rum, Slovenia (1998), 111114

PAGLIA, D.E.; VALENTINE, W.N.:

Studies on the quantitative and qualitative characterisation of erythrocyte glutathione peroxidase. J. Lab. Clin. Med. 70 (1967), 158-169

SAEZ, T,; MARCA, M.C; RAMOS, J.J; VERDE, M.T.; FERNANDEZ, A.; SANZ, M.C.:

Detección de carencias de selenio en el ganado ovino de la provincia de Zaragoza mediante la medición de la actividad glutatión peroxidasa selenio-dependiente. ITEA 91 (1995), 5-11

SAEZ, T.; RAMOS, J.J.; MARCA, M.C.; SANZ, M.C.; FERNANDEZ, A.; VERDE, M.T.:

Efecto de la inoculación de dos tipos de selenio sobre la bioquímica clínica en ganado ovino. Arch. Med. Vet. 13 (1996), 619-625

SMITH, G.M.;FRY, S.M.; ALLEN, J.G.; COSTA, N.D.:

Plasma indicators of muscle damage in a model of nutritional myopathy in weaner sheep. Aust. Vet. J. 71 (1994), 12-17

WHEATLEY, L.E.; BECK, N.F.G.:

The influence of season and husbandry on the selenium status of sheep in a deficient area. Br. Ver. J.

WEST, H.: 144 (1988), 246-251

The clearance of bromosulphthalein from plasma as measure of the changes in hepatic function during pregnancy and lactation in ewes. Br. Vet. J. 145 (1989), 506-516

WILLIAMS, B.:

Biostatistics: Concepts and applications for Biologists. Chapman and Hall, UK (1994)

ZACHARA, B.A.; TRAFIKOWSKA, U.; LEJMAN, H.; KIMBER, C.; KAPTUR, M.:

Selenium and glutathione peroxidase in blood of lambs born to ewes injected with barium selenaie. Small Rum. Res. 11 (1993), 135-141

Received: 2000-03-13

Accepted: 2001-02-27

Correspondence with the atthor

Dr. CRISTINA CASTILLO

Departamento de Patologla Animal: Medicina y Cirugia Animal

Facultad de Veterinaria

Campus Universitario $\mathbf{s} / \mathbf{n}$.

27002-LUGO

Spain

E-Mail: ccasti@correo.lugo.usc.es 